\title{
Between experimentation and validation: the Bavarian experience of eco-districts and urban regeneration policies
}

\author{
A. Maahsen-Milan \\ Department of Architecture and Urban Planning, \\ Bologna University, Italy
}

\begin{abstract}
The identification of methodologies, devices and procedures for energyfunctional recovery of social housing of Italian and European peripheries can be of peculiar value in a context of poor financial resources. The study - with a "minimalistic" approach - focuses on all phases of a building's life cycle so to improve energy-functional parameters of social housing buildings. The types of micro-interventions analyzed have been implemented at contained costs and with innovative contents. Experiences made in the sector of German Social Housing can be useful to assess ex-post the effect brought about by the combination of diverse improvement interventions within the context of residential building recovery. The original concept resides in the identification of affordable-price building and housing models, which are sustainable and sensitive to socioeconomic changes in the specific territory and surrounding metropolitan areas. Keywords: social housing, urban regeneration, metropolitan area, peripheral districts, sustainability, housing models.
\end{abstract}

\section{Foreword}

For some years now, we have been witnessing a growing attention to the identification and development of new methodologies and procedures that actually have anticipated and complemented energy-functional recovery processes in social housing in the peripheries of European cities and along the borders of old towns. This awareness can be of peculiar value in a context of poor financial resources or even in times of evident economic recession. It is a fact that pulling down old districts and replacing them with new housing units 
does not always represent the right solution to widespread housing problems nor a radical approach can be regarded as the only option. Even ambitious interventions are not always capable and able to meet pre-established specific goals and objectives.

This study is part of a broader research on the scenario of European urban regeneration. It addresses all phases of a building's life cycle so to identify a set of "best practices" that can be applied and declined in diversified contexts. Hence, we have to identify and define common operational, possibly replicable, criteria in the process of energy-functional retrofitting in social housing buildings. The categories of micro-interventions analyzed in the different case studies originate from a two-decade experimentation carried out by the Bavarian Housing Agency. All of them are realized at reasonable costs and with a high innovative content.

\section{Study scope}

Experiences completed in German Social Housing are useful for ex-post evaluation of the effect generated by the combination of diversified improvement interventions implemented in and during the process of housing recovery. Reference research, started by DIFU [Deutsches Institut für Urbanistik] on behalf of BWBW [Bundesministeriums für Verkehr, Bau- und Wohnungswesen], highlights the close correlation between labor market trends and housing needs on one side and economic contraction and recession cycles on the other side

Such focus concentrated mainly and firstly on the phenomenon of urban abandonment in areas in economic-industrial decline, especially in Eastern, former $D D R$ Länder, so to contrast it and attempting to rebalance the residential fabric of central and peripheral districts of middle-size cities involved in large migratory flows. Among the most dynamic situations of German Federal Republic, the metropolitan region of Munich and the Bavaria Land as a whole have been able to match innovative and traditional residential features by concentrating specifically on energy-environmental aspects.

In particular, Land's policies on Social Housing have become factual and effective over two decades of experimentation, deployment and monitoring conceived within the pilot project framework named Wohnmodelle Bayern. The original concept resides in the identification of affordable-price building and housing models, which are sustainable and sensitive to socio-economic changes of the territory and surrounding metropolitan areas.

\subsection{Munich: settlement tradition in the 20th century}

At the beginning of the 20th century, urban peripheries spread along territorial artery roads and followed a kind of décor bourgeois model. The anti-urban idea of Gartenstadt started to be experimented carefully without hampering the physical corpus of the Neue Stadt, and being inspired by Theodor Fischer's romantisch-malerischen Stil. 
Differently from Berlin or Rhine cities, Munich and Bavaria as a whole were not affected by the proliferation of so-called Miet-Kasernen: on the contrary, Bavarian cities became hubs of attraction for enlightened middle class, artists and intellectuals during the lively years of Jugendstil (1900-1914).

Together with Wien, Munich was certainly the Central European city that better assimilated the French model of "savoir vivre", as shown in the excellent urban and architectonic quality of its peripheral settlements. Then, the dramatic post-war period (1918-1933) placed Munich and Nuremberg at the core Nationalism and its totalitarian ideology.

World War II hit harshly the glorious Southern Capital, even if in less severely than Rhine cities. The most severe and traumatic losses were suffered almost entirely by the symbol-city, Nuremberg, which was fully disfigured [1].

\subsection{Post-war residential reconstruction}

The dramatic years after World War II took a softer outline in the framework of the allied occupation governed by Anglo-American military. The launch of the Marshall Plan (European Recovery Program - ERP) and the entrance of Bavaria in the newly-established federal state (1948) helped to start a new pathway in the reconstruction of entire districts while acknowledging a change in the cultural atmosphere, which was beginning to open to new settlement models with an international outlook.

The result, sometimes partially poor in mediation and cultural "digestion", has been the typological functionalism of so-called Neues Bauen and also a kind of social democracy paradigm of Swiss, North European and Anglo-American inspiration applied to social housing..

\subsubsection{The Wirtschaftswunder years [German economic miracle] - 1948-1958}

The new districts were located in peripheral areas, not far from urban centres and often totally "released" from the old town, on which the debate focus did concentrate in terms of reconstruction and innovative solutions. On the other hand, the need for housing did not allow the debate to be refined: the demand for houses replacing the destroyed ones became a priority as well as the starting demand for new housing to host ethnic minorities, rural populations flocking to urban areas and thousands of refugees from Eastern Germany.

Such number increased from the first half of the fifties and brought about the need to introduce quotas for seasonal workers (Saisonarbeiter) and later on for migrant workers (Gastarbeiter) as well [2].

\subsubsection{Social housing districts: migration, conflicts and integration}

Since the seventies, thousands of foreign (Italian, Portuguese, Greek, Turkish) workers have started to become permanent residents thanks to the changes to federal labor policies and the possibility of family reunification [3]. Changes in Federal migration policies determined and deeply characterized settlement forms. If the social democratization process of the seventies marked an opening and a positive attitude towards foreign workers and their families, the cultural 
backlash following the so-called "Lead Years" slowed down or even stopped the reform actions.

New migration waves, coming first from Turkey and the former DDR and secondly from Eastern Bloc countries, brought to the forefront, for the first time after World War II, the "ethnic-cultural" issue so triggering the debate on the rights of newcomers - new citizens..

\section{Social innovation, urban re-generation}

The nineties, after the European Energy Crisis, represented for re-unified Germany an extraordinary time for experimentation in social innovation and urban regeneration. The entrance into the new Millennium highlighted the bottom-up approach pushed by political-social movements so stressing priority and focus on programs aimed at environmental protection and energy-efficient solutions. A vision that, although not always consistent, continued to root and germinated the current integrated political approach regarding Social Housing.

A “green" Germany caring for social inclusion has made steps forwards and is now main player in European projects as well as in the old and new Bundesländer. Bavaria, with a conservative political tradition, started a new pathway towards technological innovation aimed at supporting the environment, the natural habitat and preservation of sustainable living conditions.

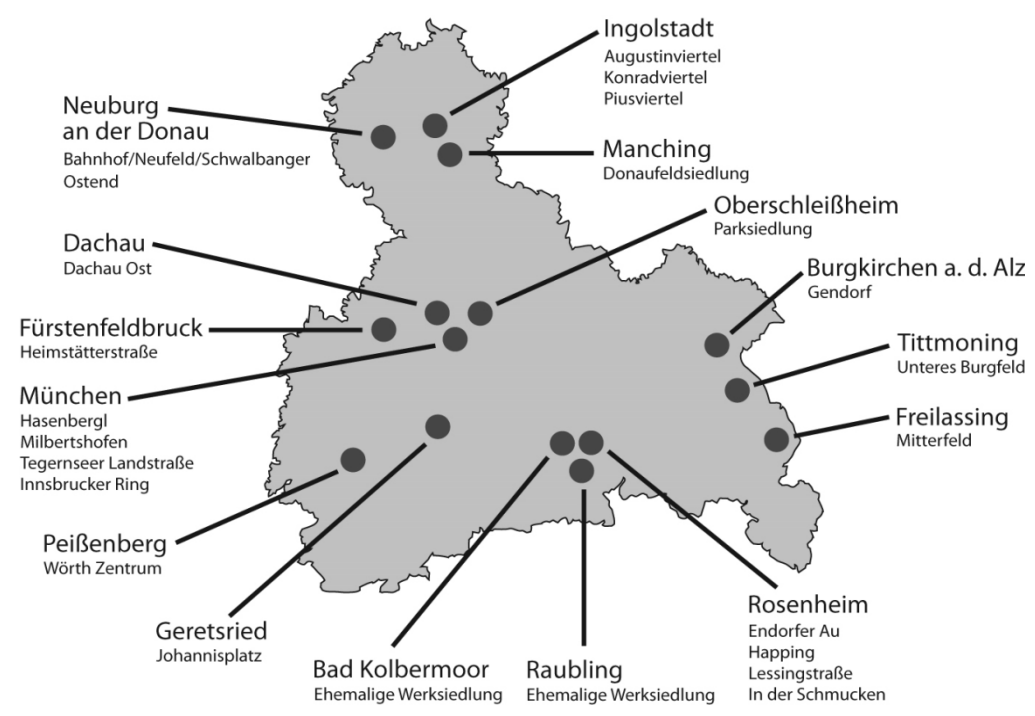

Figure 1: Urban re-generation interventions in the metropolitan area of Munich and in Oberbayern. [C Landeshauptstadt München]. 


\subsection{Typological experimentations and social housing reforms}

The action of the Land's policies on Social Housing carried out over a span of two decades of experimentation was fostered by the pilot project "Wohnmodelle Bayern" that gave birth to an estate of 4,500 houses constantly monitored during their whole life cycle by the regional Ministry of the Interiors.

The fundamental concept at the root of the governmental actions focuses on the study of low-cost buildings and settlement models as well as on sustainable and sensitive socio-economic changes taking place in the intervention and metropolitan area.

The case studies related to Munich metropolitan area are part of an ambitious plan of building recovery and triggered the renewal project for Social Housing interventions always aiming at reducing energy-related costs (Figure 1).

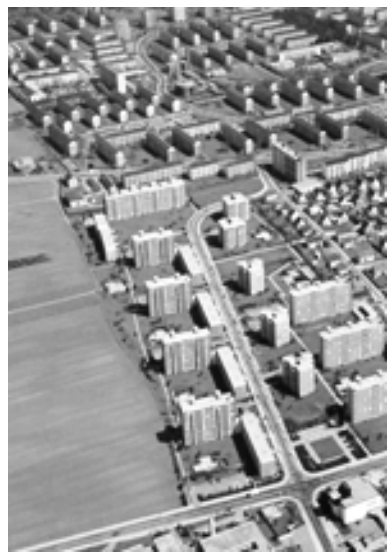

(a)

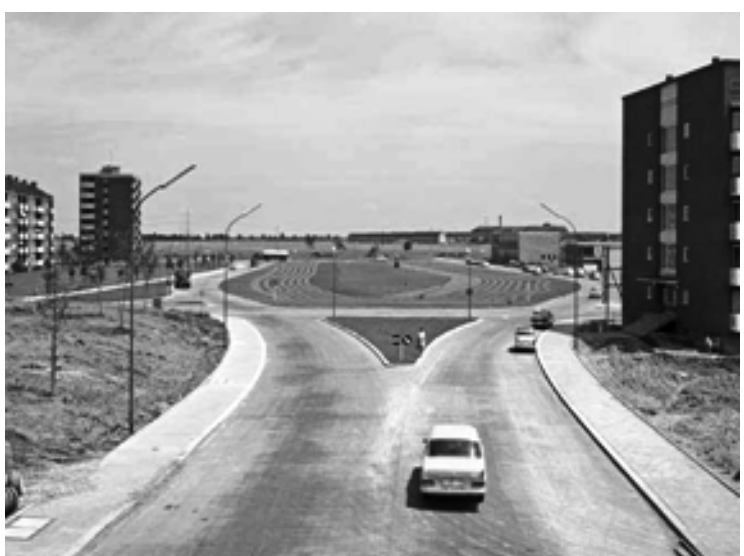

(b)

Figure 2: Social housing district of Hasenbergl, before and after recovery interventions. (a) Housing blocks, (aerial photo of 1980); (b) Dülferstraße in 1963.

The program named “die Soziale Stadt" ["Social City"] promoted by Munich municipality, is characterized with remarkable inclusive initiatives (integrated action plan), which envisage a set of measures - from language courses to leisure activities, district parties, citizen counselling services - all aimed at supporting and improving pragmatically the living conditions of social housing residents. According to the Public Administration's intentions:

"[...] the interaction of the different professionals with the district's population plays a central role in the program "Social City". The integrated action plan includes the objectives of urban development, since the start of implementation, together with the district's population, it has been continuously developed to date. All that required concerted action in the fields of urban design, open space, social aspects, culture, education, healthcare, ecology and economics. Especially in neighborhoods that have both strong and weak points, 
only tailor-made projects and actions can support sustainable development and provide equal opportunities for all generations in the long run. [...] The program "Social City" expands the action areas of the existing urban renewal and urban development. Local issues such as economics or socio-spatial action are equally important as architectural, urban design and green arrangements and as environmental objectives. A holistic approach to action summarizes the various fields of activity, funding opportunities and players. By focusing all resources in the program areas, shortly and quickly self-supporting structures and the basis for a sustained upward trend will be created". [...] Projects supported under the funding opportunities arise in the process of neighborhood development with the participation of stakeholders and local players. Grant applications can generally be found in the district coordination, which is brought about by the Executive Office for Urban Planning in the coordination group" [4].

The projects are part of the development strategy of the integrated action concept and cover multiple areas of activity: housing, living, environment, noise; public space and public green; urban shapes, urban structures and traffic; social infrastructure, healthcare; education and leisure; co-existence in the district, district culture, citizens' participation; job market and employment situation.

Building interventions by GWG-München, municipal housing agency [5] comply both with the construction of new buildings as per sustainability principles [6] and with performance interventions of energy improvement in the existing estate [7].

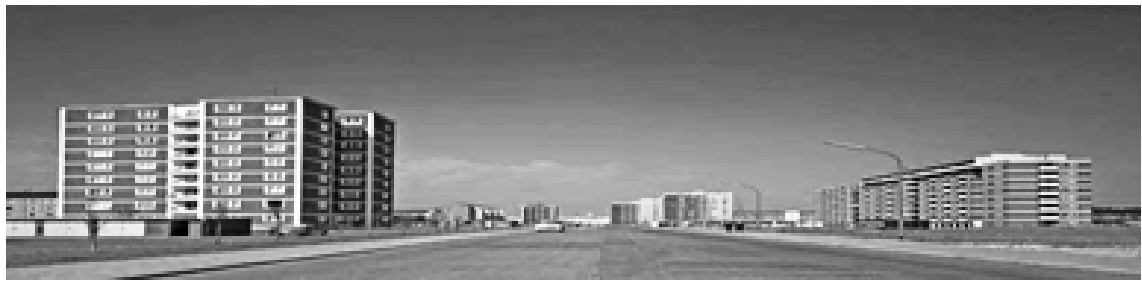

(a)

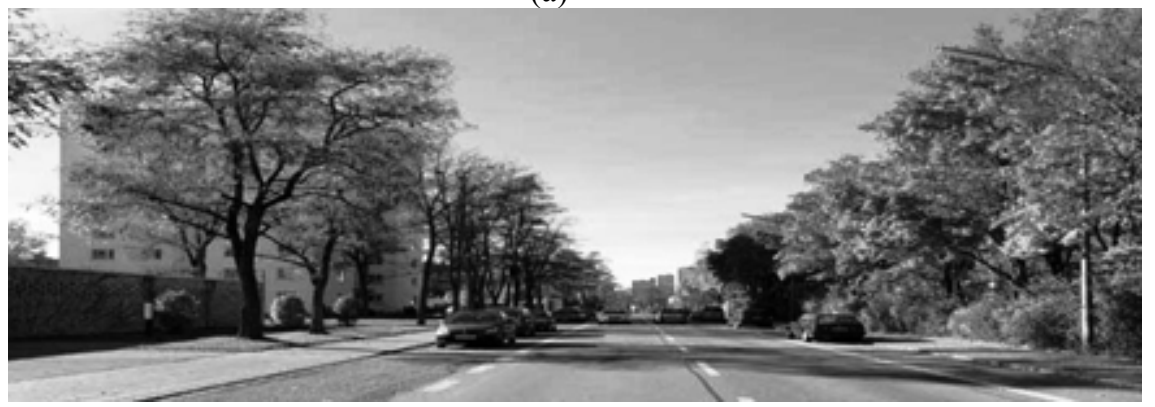

(b)

Figure 3: Social housing district of Hasenbergl, before and after recovery interventions. (a) Aschenbrennerstraße in 1963 and (b) in 2010. [Photos (C) Landeshauptstadt München]. 
Such complementary interventions can be understood and regarded as a complement helping densification, upgrading of housing volumes and unbundling of housing units. These measures are complemented by the creation or re-arrangement of commercial services and care facilities as well as by recovering public and private green areas. Environmental arrangements were carried out also with a kind of "sight mitigation" approach of vehicle parking facilities.

\subsection{Typological experimentations and social housing reforms}

Among the most interesting and admirable examples it is worth mentioning the recovery of social housing districts of München-Hasenbergl and Milbertshofen, carried out in the period 1993-2000. The interventions in Innsbruckring/ Baumkirchnerstraße in the suburbs of Berg am Laim and Ramersdorf and Tegernseestraße/Chiemgaustraße in Giesing's district, are still in progress and regard urban areas of special architectonic and environmental interest.

The suburbs, still preserving dense pre-existing urban features and often placed around and along historical Siedlungen [settlements] of the thirties/forties, are getting re-organized and connected with dedicated cycle-pedestrian tracks, designed along and on old tracks and pathways.

Moreover, new open spaces and small places are being built for different social groups so to foster gatherings close to recovered historical buildings: special attention is then given to the preservation of small proximity shops or district services.

\subsection{Green areas and historical heritage as drivers for urban re-generation}

The most relevant environmental recovery interventions entail the shielding against noise caused by traffic. Building plans managed in teamwork with and on behalf of GWG [8] match the functional recovery of flats with the creation of public spaces and with the renewal of green areas.

Hasenbergl's district is one of the major Siedlungen after WWII, built to meet the endemic demand for houses: the residential accommodations accomplished between the beginning of the sixties and 1971 are made of "bloc" buildings arranged as per the typical plan envisaged by federal land use planning norms: serial and multi-level, with wide free surfaces for parking .

Over time, beyond a widespread structural decline, the "make-up activities" implemented spontaneously by the residents have drastically changed the appearance of the buildings side by side with the shift from autochthonous users to and ever-increasing presence of users mainly coming from non-European countries.

Regenerative interventions started in 1993 and primarily concentrated on one of the districts at highest "social risk". The initiative, carried out with participatory criteria, was finalized in 1999 with the full recovery of the buildings, energy-functional retrofitting and opening of new community centres. Upon termination, substantial decrease in social "deprivation" phenomena was observed, with a special positive effect on youngsters (Fig. 2). 


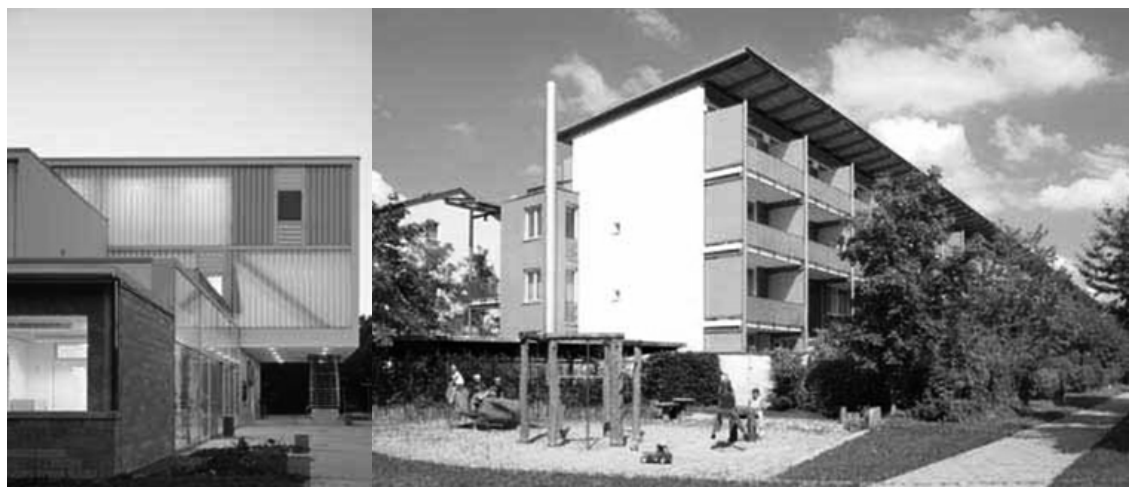

(a)

(b)

Figure 4: München-Hasenbergl. New services and residence re-qualification. (a) Community Center “Junge Arbeit" München); (b) multi-storey building on Kienestraße [Photos $($ Landeshauptstadt München].

\subsection{Building re-generation: "weak users and protected persons"}

Residential accommodations are fitted with small day care services and protected shared housing for the elderly, avoiding hospitalization and social isolation.

During such experimentation, specific focus was given to the building and/or implementation of so-called XXL flats for large and multi-generation households, so to enable and support improvement in living conditions while trying to reduce home care costs for the elderly.

Policies supporting specific demand segments focused also on the growing need for "gender" social safety: shared housings for single women, old ladies, etc., granted at a special social fee (Fig. 4).

The building initiatives have been and are still managed by cooperatives Frauen Wohnen eG - aiming at matching civil rights (diversity tolerance, social inclusion, fight against gender discrimination, etc.) with environmental sustainability principles [9].

\subsection{Eco-districts and pedestrian mobility}

Often such typological experimentations are carried out in car-free "pilotdistricts" (autofreie Siedlungen), as in the case of München-Riem, nearly completed, built in the area of the old Munich airport and now partially occupied by Hallen [pavilions] of the Trade Fair Centre. Such interventions show and have a considerable symbolic value as they generated from and thanks to wellestablished relationships among different stakeholders: communities, local government and agencies active in the field of housing rights. It is not a case that very often, such very same settlements - that have been able to attract considerable economic investments - are awarded with regional or national prizes [10] (Fig. 5). The search for higher energy efficiency involves also formal- 
functional aspects of the buildings, so bringing about considerable changes in anthropogenic and urbanized areas. Regenerative policies stress energy efficiency as primary goal - Germany is rapidly halving its energy demand in civil building.. Indeed the obligation to comply with energy saving guidelines evolves consistently with the design of articulated policies for the recovery of public space and green areas: expected and already achieved results show an outstanding improvement in the quality of life while developing environmental and socio-cultural features and peculiarities participated by and with the citizens.

\section{Conclusions}

Energy saving and urban re-generation policies have led, in less than two decades, to a remarkable recovery of housing heritage of peripheries and urban centres. Many interventions fall within the category of pure architectonic recovery by actions of mending and densification: a drive for formal requalification of the environment in view of "making a new city".

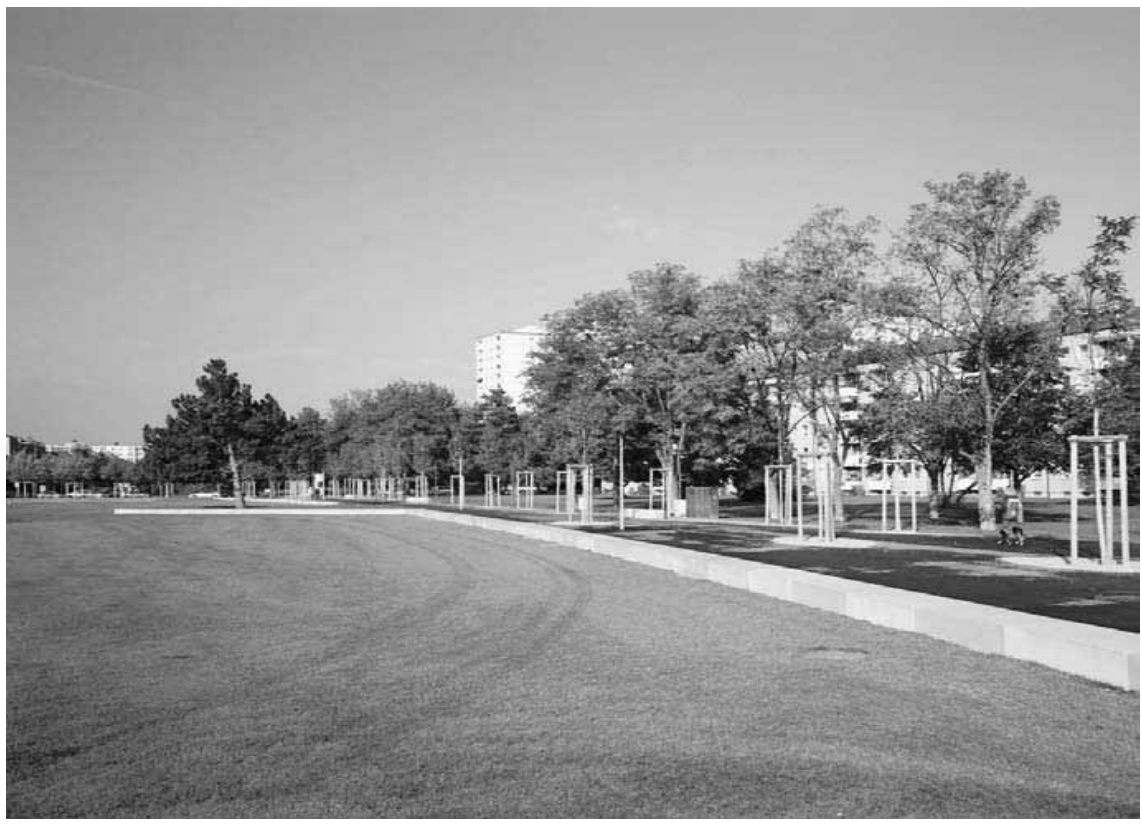

Figure 5: München-Hasenbergl. Re-qualification of open spaces. External boulevard "Dülferanger": new cycle-pedestrian track.

Recreating community and leisure places, which are almost absent or insufficient, does not anymore mean, as in the eighties, "reducing historical spaces"; it means to intervene and operate on the use of public space with a minimal but well-targeted and flexible approach [11]. 
The focus on social innovation is maybe the element mostly characterizing the quality achieved in the years after 2008 economic crisis. Confronted with economic mechanisms of social marginalization and exclusion, public bodies and agencies have been able to start diversified and tailored actions, still granting care allowances to socially weak people and guaranteeing protection of rights.

The prevailing trend is the development of initiatives to support people selfreliance, from access to employment to communication facilitation (language learning and multimedia; actions for social and gender integration; intercultural dialogue etc.) [12].

The Bavarian lesson points out how "sustainability" increasingly implies the growth of a kind of "proactive citizenship" that goes beyond the pure "user's participation" approach in conceiving and managing interventions. Such shared goal is improving quality of life and of social cohesion: public decision-makers act as "complement" to support information, awareness-raising, responsible use of the environment and public assets, while recognizing and respecting identity values.

\section{References}

[1] Durth W., Beyme K. v., Gutschow N., Nerdinger W., Topfstedt T., Neue Städte aus Ruinen. Deutscher Städtebau der Nachkriegszeit, München, 1992.

[2] Herbert U., Geschichte der Ausländerpolitik in Deutschland. Saisonarbeiter, Zwangsarbeiter, Gastarbeiter, Flüchtlinge, Beck, München, 2001.

[3] Schlemmer Th., Woller H., Bayern im Bund: Gesellschaft im Wandel 1949 bis 1973, Institut für Zeitgeschichte Oldenbourg, München, 2002.

[4] From: Soziale Stadt München, http://www.sozialestadt-muenchen.de/

[5] GWG-Gemeinnützige Wohnstätten- und Siedlungsgesellschaft $\mathrm{GmbH}$, München; Uli W., Sozialer Wohnungsbau in München, Bruckmann, München, 1993.

[6] Cfr. Corporate Social Responsibility Report-Bericht über die nachhaltige Entwicklung bei der GWG, München, 2011. Eurhonet Program - European Housing Network und CSR - Corporate Social Responsibility. with: France; Italy; Germany (Bauverein AG Darmstadt, GBG Mannheim, GWG München; DOGEWO21 Dortmund, LWB Leipzig); Sweden; England.

[7] These are housing usually built as bloc or line, much more rarely as tower during the period after WWII, 1950-1990.

[8] München-Hasenbergl - Lebensqualität am Stadtrand, in: "Stadt und Raum", n.3/11, München, 2011, www.stadtundraum.de.

[9] Kastner B., Das weibliche Wohn-Prinzip. Individualität in der Gemeinschaft: Frauen planen zwei Genossenschafts-Häuser. Süddeutsche Zeitung, 20. 1. 2004, http://www.frauenwohnen-eg.de/presse/presse.php

[10] Zacharias Landschaftsarchitekten Anita-Augspurg-Preis 2007; Bayerischer Wohnungsbaupreis 2007; Deutscher Bauherrenpreis 2008 Ehrenpreis der LHM für guten Wohnungsbau, Wohnen im Alter und vorbildliche 
Sanierung 2010; BDLA Deutscher Landschafts- architekturpreis Sonderpreis Wohnumfeld 2011, Würdigung.

[11] Krüger A., Erneuerung der Erneuerung - Eine neue Rolle der Stadterneuerung im Kontext von Benachteiligungsphänomenen in der Stadtentwicklung. (ISR Graue Reihe Heft 10). Institut für Stadt- und Regionalplanung, TU Berlin, 2008.

[12] Gemeinschaftsinitiative Soziale Stadt. Eine Zwischenbilanz, http://www.regierung.oberbayern.bayern.de/aufgaben/planung/staedtebau/s ozial/ 